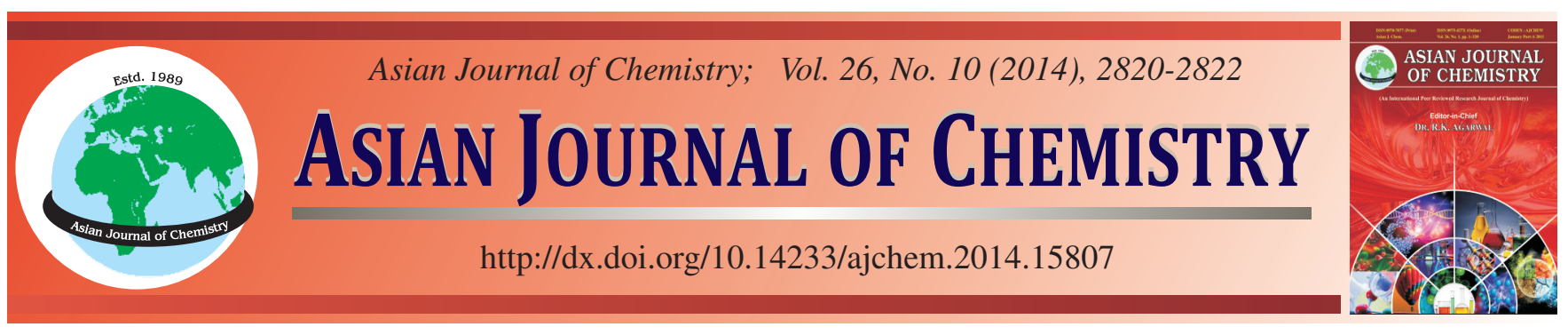

\title{
A New Coumarin from Roots and Stems of Flue-Cured Tobacco and its Anti-Tobacco Mosaic Virus Activity
}

Wei Liu, Jia Wu, Sujuan Wang, Weisong Kong, Yunhua Qin, Guangyu Yang and Yongkuan Chen*

Key Laboratory of Tobacco Chemistry of Yunnan Province, Yunnan Academy of Tobacco Science, Kunming 650106, P.R. China

*Corresponding author: E-mail: cyk1966@163.com,ygy1110@163.com

A new coumarin, 6-hydroxy-3-(4-hydroxyphenyl)-7-methoxy-2H-chromen-2-one (1), was isolated from the roots and stems of fluecured tobacco (a variety of Nicotiana tabacum L). Its structure was elucidated by spectroscopic methods, including extensive 1D and 2D NMR techniques. Compound 1 was tested for its anti-tobacco mosaic virus (anti-TMV) activity and it shows potential anti-tobacco mosaic virus activity with inhibition rates of $23.6 \%$.

Keywords: Coumarin, Flue-cured tobacco, Structure elucidation, Anti-tobacco mosaic virus activity.

\section{INTRODUCTION}

The flue-cured tobacco belongs to the plants of nicotiana genus. It is a type of cigarette tobacco. Along with burley tobacco, it accounts for more than $90 \%$ of world tobacco production $^{1,2}$. In addition to being used in cigarette industry, the flue-cured tobacco is also used as insecticide, anesthetic, diaphoretic, sedative and emetic agents in Chinese folklore medicine due to containing many useful chemical compounds $s^{1,3-5}$. Previous phytochemical studies of flue-cured tobacco have shown the presence of terpenoids ${ }^{6-8}$, alkaloids ${ }^{9,10}$, lignans ${ }^{11,12}$, flavonoid $^{13}$, phenylpropanoids ${ }^{14}$ and the homologous. The roots and stems of flue-cured tobacco are big amount of by-product in tobacco planting and are normally used as organic fertilizer. The multipurpose utilization of the roots and stems of flue-cured tobacco is an interesting topical and receives more and more attentions ${ }^{15-17}$. Motivated by a search for new bioactive metabolites from this plant, our group has investigated the chemical constituents of the roots and stems of flue-cured tobacco. As a result, a new coumarin (1) was isolated. This article deals with the isolation, structural elucidation and the anti-tobacco mosaic virus (anti-TMV) activity of this new compound.

\section{EXPERIMENTAL}

Ultra-violet spectra were obtained using a Shimadzu UV2401A spectrophotometer. Infrared spectra were obtained in $\mathrm{KBr}$ disc on a Bio-Rad Wininfmred spectrophotometer. ESIMS were measured on a VG Auto Spec-3000 MS spectrometer.
${ }^{1} \mathrm{H},{ }^{13} \mathrm{C}$ and 2D NMR spectra were recorded on Bruker DRX500 instrument with TMS as internal standard. Column chromatography was performed on silica gel (200-300 mesh), or on silica gel H (10-40 $\mu \mathrm{m})$, Qingdao Marine Chemical Inc., China). Preparative HPLC was used an Agilent 1100 HPLC equipped with ZORBAX-C18 (21.2 mm × $250 \mathrm{~mm}, 7.0 \mathrm{~mm})$ column and DAD detector.

The roots and stems of flue-cured tobacco were collected in Honghe Prefecture, Yunnan Province, People's Republic of China, in September 2011. The identification of the plant material was verified by Prof. Chen Y. J (Yunnan University of Nationalities).

Extraction and isolation: The air-dried and powdered roots and stems of flue-cured tobacco $(2.2 \mathrm{~kg})$ were extracted four times with $70 \%$ aqueous acetone $(3 \times 5 \mathrm{~L})$ at room temperature and filtered to yield a filtrate. The crude extract (183 g) was applied to silica gel (200-300 mesh) column chromatography, eluting with a chloroform-acetone system (20:1, 9:1, 8:2, 7:3, 6:4, 5:5), to give six fractions A-F. The further purification of fraction $\mathrm{C}(8: 2,14.8 \mathrm{~g})$ by silica gel column chromatography, eluted with petroleum ether-acetone $(8: 2,7: 3$, 6:4, 5:5, 0:1), yielded mixtures C1-C5. Fraction C4 (1:1, $1.81 \mathrm{~g})$ was subjected to preparative $\mathrm{HPLC}\left(40 \% \mathrm{MeOH}-\mathrm{H}_{2} \mathrm{O}\right.$, flow rate $12 \mathrm{~mL} / \mathrm{min}$ ) to yield compound $\mathbf{1}(15.8 \mathrm{mg})$.

6-Hydroxy-3-(4-hydroxyphenyl)-7-methoxy-2Hchromen-2-one (1): $\mathrm{C}_{16} \mathrm{H}_{12} \mathrm{O}_{5}$; obtained as yellow gum; UV $\left(\mathrm{CH}_{3} \mathrm{OH}\right), \lambda_{\max }(\log \varepsilon) 275$ (3.89), 220 (4.32) nm; IR (KBr, $\left.v_{\max }, \mathrm{cm}^{-1}\right) 3435,1717,1589,1511,1486,1438,1266,1174$, 1076, 890; ${ }^{13} \mathrm{C}$ NMR and ${ }^{1} \mathrm{H}$ NMR data $\left(\mathrm{C}_{5} \mathrm{D}_{5} \mathrm{~N}, 500\right.$ and 125 
MHz) see Table-1; postive ESIMS $m / z 307[\mathrm{M}+\mathrm{Na}]^{+}$; postive HRESIMS $m / z 307.0586\left[\mathrm{M}+\mathrm{Na}^{+}\right.$(calcd. for $\mathrm{C}_{16} \mathrm{H}_{12} \mathrm{NaO}_{5}$, 307.0582).

\section{RESULTS AND DISCUSSION}

The air-dried and powdered roots and stems of flue-cured tobacco $(4.5 \mathrm{~kg})$ was extracted with $70 \%$ aqueous acetone $(3 \times 5 \mathrm{~L})$ at room temperature and filtered to yield a filtrate, which was successively evaporated under reduced pressure to obtained a crude extract (183 g). This crude extract was subjected repeatedly to column chromatography on silica gel, Sephadex LH-20, RP-18 and preparative HPLC to afford the new compound $\mathbf{1}$. The structures of the compound $\mathbf{1}$ were as shown in Fig. 1 and its ${ }^{1} \mathrm{H}$ and ${ }^{13} \mathrm{C}$ NMR data were listed in Table-1.

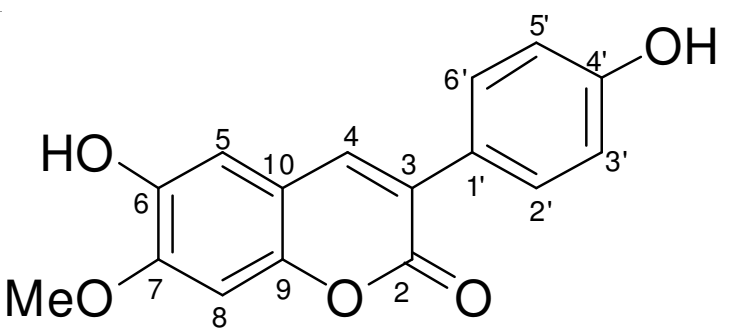

Fig.1. Structure of new coumarin

\begin{tabular}{|c|c|c|c|c|c|}
\hline \multicolumn{6}{|c|}{$\begin{array}{c}\text { TABLE } 1 \\
{ }^{1} \mathrm{H} \text { NMR AND }{ }^{13} \mathrm{C} \text { NMR DATA OF COMPOUND } 1 \\
\left(\mathrm{C}_{5} \mathrm{D}_{5} \mathrm{~N}, \delta, \mathrm{ppm}, \mathrm{J} / \mathrm{Hz}\right)\end{array}$} \\
\hline No. & $\delta_{\mathrm{C}}$ (mult.) & $\begin{array}{c}\delta_{\mathrm{H}}(\text { mult, } \\
\mathrm{J}, \mathrm{Hz})\end{array}$ & No. & $\begin{array}{c}\delta_{\mathrm{C}} \\
\text { (mult.) }\end{array}$ & $\begin{array}{c}\delta_{\mathrm{H}}(\text { mult, } \mathrm{J}, \\
\mathrm{Hz})\end{array}$ \\
\hline 2 & $162.5 \mathrm{~s}$ & & 10 & $112.6 \mathrm{~s}$ & \\
\hline 3 & $121.4 \mathrm{~s}$ & & $1^{\prime}$ & $128.3 \mathrm{~s}$ & \\
\hline 4 & $139.7 \mathrm{~d}$ & $7.89 \mathrm{~s}$ & $2^{\prime}, 6^{\prime}$ & $129.3 \mathrm{~d}$ & $7.75 \mathrm{~d}(8.6$ \\
\hline 5 & $112.8 \mathrm{~d}$ & $7.08 \mathrm{~s}$ & $3^{\prime}, 5^{\prime}$ & $114.2 \mathrm{~d}$ & $6.92 \mathrm{~d}(8.6$ \\
\hline 6 & $142.5 \mathrm{~s}$ & & $4^{\prime}$ & $158.8 \mathrm{~s}$ & \\
\hline 7 & $152.2 \mathrm{~s}$ & & 7-OMe & $55.9 \mathrm{q}$ & $3.83 \mathrm{~s}$ \\
\hline 8 & $103.4 \mathrm{~d}$ & $6.65 \mathrm{~s}$ & Ar-OH-6 & & 11.26 brs \\
\hline 9 & $148.3 \mathrm{~s}$ & & $\mathrm{Ar}-\mathrm{OH}-4^{\prime}$ & & 11.02 brs \\
\hline
\end{tabular}

Compound 1 was isolated as a yellow gum. High-resolution ESIMS analysis gave an quasi-molecular ion at $\mathrm{m} / \mathrm{z}$ $307.0586[\mathrm{M}+\mathrm{Na}]^{+}$(calcd. 307.0582), consistent with a molecular formula of $\mathrm{C}_{16} \mathrm{H}_{12} \mathrm{O}_{5}$, which indicated 11 degrees of unsaturation. Its UV spectrum showed the maximum absorption at 275 and $220 \mathrm{~nm}$. Strong absorption bands accounting for hydroxy $\left(3435 \mathrm{~cm}^{-1}\right)$, carbonyl $\left(1717 \mathrm{~cm}^{-1}\right)$ and aromatic groups $\left(1589,1511,1486 \mathrm{~cm}^{-1}\right)$ could also be observed in its IR spectrum. The ${ }^{1} \mathrm{H}$ and ${ }^{13} \mathrm{C}$ NMR spectra of $\mathbf{1}$ (Table-1) displayed signals for all 16 carbons and 12 protons, including a 3,6,7-subsititued-coumarin system $\left(\delta_{\mathrm{C}} 162.5 \mathrm{~s}\right.$, $121.4 \mathrm{~s}, 139.7 \mathrm{~d}, 112.8 \mathrm{~d}, 142.5 \mathrm{~s}, 152.2 \mathrm{~s}, 103.4 \mathrm{~d}, 148.3 \mathrm{~s}$, $112.6 \mathrm{~s} ; \delta_{\mathrm{H}} 7.89 \mathrm{~s}, 7.08 \mathrm{~s}, 6.65 \mathrm{~s}^{18}$, a para-subsititued phenyl moiety $\left[\delta_{\mathrm{C}} 128.3 \mathrm{~s}, 129.3 \mathrm{~d}(2 \mathrm{C}), 114.2 \mathrm{~d}(2 \mathrm{C}), 158.8 \mathrm{~s} ; \delta_{\mathrm{H}}\right.$ 7.75 (d) $J=8.6(2 \mathrm{H}), 6.92$ (d) $J=8.6(2 \mathrm{H})]^{19}$, one methoxy group $\left(\delta_{\mathrm{C}} 55.9 \mathrm{q} ; \delta_{\mathrm{H}} 3.83 \mathrm{~s}\right)$ and two phenolic hydroxy group $\left(\delta_{\mathrm{H}} 11.26\right.$ and 11.02 brs). The HMBC correlation (Fig. 2) of one phenolic hydroxyl proton $\left(\delta_{\mathrm{H}} 11.02\right)$ with $\mathrm{C}-3^{\prime}, 5^{\prime}\left(\delta_{\mathrm{C}}\right.$ $114.2), \mathrm{C}-4^{\prime}\left(\delta_{\mathrm{C}} 158.8\right)$ showed a phenolic hydroxyl group was located at C-4'. The HMBC correlations between $\mathrm{H}-2$ ',6' $\left(\delta_{\mathrm{H}}\right.$ $7.75)$ and $\mathrm{C}-3\left(\delta_{\mathrm{C}} 121.4\right), \mathrm{H}-4\left(\delta_{\mathrm{H}} 7.89\right)$ and $\mathrm{C}-1^{\prime}\left(\delta_{\mathrm{C}} 128.3\right)$ concluded the linkage of the $p$-hydoroxyphenyl was located at the C-3 position of the coumarin system. The location of another phenolic hydroxy group was assigned to C-6 position on the basis of HMBC correlation between the hydroxy proton signal $\left(\delta_{\mathrm{H}} 11.26\right)$ and $\mathrm{C}-5\left(\delta_{\mathrm{C}} 112.8\right), \mathrm{C}-6\left(\delta_{\mathrm{C}} 142.5\right)$ and C-7 $\left(\delta_{\mathrm{C}} 152.2\right)$. Finally, a methoxy group at $\mathrm{C}-7$ position was supported by the HMBC correlation observed between methoxy proton $\left(\delta_{\mathrm{H}} 3.83\right)$ and $\mathrm{C}-7\left(\delta_{\mathrm{C}} 152.2\right)$. On the basis of the above evidence, the structure of 1 was established as 6hydroxy-3-(4-hydroxyphenyl)-7-methoxy-2H-chromen-2one.

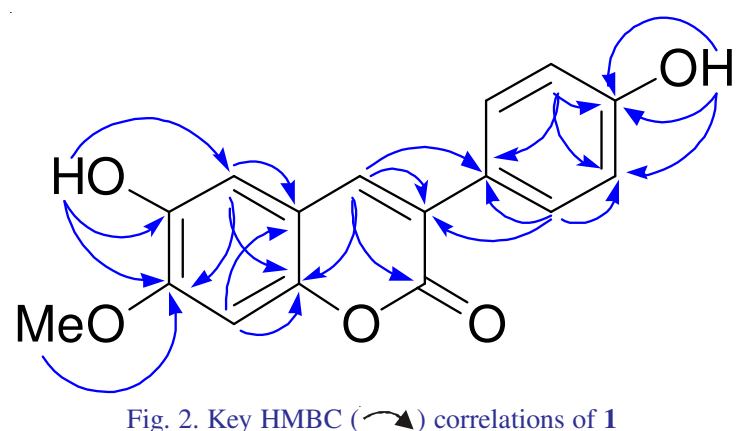

Since certain of the phenolic compounds exhibit potential anti-TMV activity ${ }^{19-21}$, compounds $\mathbf{1}$ was tested for its antitobacco mosaic virus activity. The anti-TMV activities were tested using the half-leaf method ${ }^{21}$. Ningnanmycin (2\% water solution), a commercial product for plant disease in China, was used as a positive control. The results showed that compound 1 exhibited inhibition rates of $23.6 \%$.

\section{ACKNOWLEDGEMENTS}

This project was supported financially by the National Natural Science Foundation of China (No. 31360081) the Basic Research Foundation of Yunnan Tobacco Industry Co. Ltd (2012JC01), the National Natural Science Foundation of China (No. 21002085), the Excellent Scientific and Technological Team of Yunnan High School (2010CI08).

\section{REFERENCES}

1. The Editorial Committee of the Administration Bureau of Flora of China, Flora of China, 67 vols., Beijing Science and Technology Press, Beijing (2005)

2. T.W. Hu and Z. Mao, Tob. Control, 15(suppl 1), i37 (2006).

3. A. Rodgman and T.A. Perfetti, The Chemical Components of Tobacco and Tobacco Smoke. CRC Press, Taylor and Francis Group, Boca Raton, Florida (2008).

4. A.P. Cavender and M. Alban, J. Ethnobiol. Ethnomed., 5, 3 (2009).

5. A. Inta, P. Shengji, H. Balslev, P. Wangpakapattanawong and C. Trisonthi, J. Ethnopharmacol., 116, 134 (2008).

6. X. Feng, J.-S. Wang, J. Luo and L.-Y. Kong, J. Asian Nat. Prod. Res., 12, 252 (2010).

7. Y. Shinozaki, T. Tobita, M. Mizutani and T. Matsuzaki, Biosci. Biotechnol. Biochem., 60, 903 (1996).

8. T. Pettersson, A.M. Eklund and I. Wahlberg, J. Agric. Food Chem., 41, 2097 (1993).

9. X.C. Wei, S.C. Sumithran, A.G. Deaciuc, H.R. Burton, L.P. Bush, L.P. Dwoskin and P.A. Crooks, Life Sci., 78, 495 (2005).

10. T. Braumann, G. Nicolaus, W. Hahn and H. Elmenhorst, Phytochemistry, 29, 3693 (1990). 
11. Y.K. Chen, X.S. Li, G.Y. Yang, Z.Y. Chen, Q.F. Hu and M.M. Miao, J. Asian Nat. Prod. Res., 14, 450 (2012).

12. Q.-F. Hu, G. Yang, X. Li, X. Yang, H. Mu, Y. Chen and X.-M. Gao, Heterocycles, 85, 147 (2012).

13. Z.Y. Chen, J.L. Tan, G.Y. Yang, M.M. Miao, Z.Y. Chen and T.F. Li, Phytochem. Lett., 5, 233 (2012).

14. Y. Chen, T. Li, Z.-Y. Chen, G. Yang, M. Miao and J. Tan, Heterocycles, 83, 2381 (2011).

15. W. Li, L.B. Zhang, J.H. Peng, N. Li and X.Y. Zhu, Ind. Crops Prod., 27, 341 (2008)

16. Q. Hu, M. Miao, W. Zhao, T. Zhang, L. Wan, G. Yang, Y. Chen and D. Mou, Heterocycles, 85, 2485 (2012).
17. W.H. Zhong, C.J. Zhu, M. Shu, K.D. Sun, L. Zhao, C. Wang, Z.J. Ye and J.M. Chen, Bioresour. Technol., 101, 6935 (2010).

18. J.F. Liu, K.P. Xu, F.S. Li, J. Shen, C.P. Hu, H. Zou, F. Yang, G.R. Liu, H.L. Xiang, Y.J. Zhou, Y.J. Li and G.S. Tan, Chem. Pharm. Bull. (Tokyo), 58, 549 (2010).

19. J.X. Chen, H.Q. Leng, Y.X. Duan, W. Zhao, G.Y. Yang, Y.D. Guo, Y.K. Chen and Q.F. Hu, Phytochem. Lett., 6, 144 (2013).

20. Q.F. Hu, B. Zhou, J.M. Huang, X.M. Gao, L.D. Shu, G.Y. Yang and C.T. Che, J. Nat. Prod., 76, 292 (2013).

21. Q.F. Hu, B. Zhou, X.M. Gao, L.Y. Yang, L.D. Shu, Y.Q. Shen, G.P. Li, C.T. Che and G.Y. Yang, J. Nat. Prod., 75, 1909 (2012). 